\title{
Civil-Society Organizations' Capacity Building in the Local Governmental Sector: Is It Working? A Case Study
}

\author{
Réka Zsuzsánna Máthé1, György Hajnal ${ }^{2}$
}

\begin{abstract}
The role that a strong civil society plays in socio-economic development is a subject of major scholarly attention today. Many benefits from having a strong civil society are reported in the literature. There is, however, no generally accepted view regarding how capacity-building efforts can help to develop a strong civil society, especially in the Central and Eastern European countries.

The purpose of this qualitative study is to understand the causal mechanisms existing between capacity-building efforts, a strengthened civil society and socioeconomic development. This case study suggests that a Hungarian local government did appear to strengthen associational activities in its community. Using process tracing, the research identifies specific factors that lead this village to take these uncommon steps, and it assesses the implications for civic life.
\end{abstract}

\section{Key words:}

local government, civil society, policy, civic participation, Hungary, process-tracking

\section{Introduction}

Since Almond and Verba's (1963) and Putnam's (1993) works, the civil society has been associated with better-performing government, economic growth and social

1 PhD Student, National University of Public Service, Budapest, Hungary.

2 Professor, Head of Department of Public Policy and Management, Corvinus University of Budapest, and Research Chair of the Centre for Social Research of the Hungarian Academy of Sciences (CSR HAS), Budapest, Hungary. 
cohesion. Numerous studies of the various fields of social sciences have taken note of the concept of the civil society and have adopted them, resulting in a series of different conceptualizations and operationalization. Policies have been developed to strengthen the civil society in an attempt to improve government performance and increase socio-economic well-being. Researchers have tried to investigate the causal relationship between policies of capacity building, the civil society and socioeconomic development. However, no generally accepted direction of causal links has been found so far.

This study aims to contribute to this line of scholarship by presenting a case study of a Hungarian local government's possible influence in strengthening their civil society. We first present the relevant concepts related to the civil society. Next, we present the dominant generally accepted theories that should account for the outcome. The theoretical part is followed by the research question and research methods. Then we will turn to the empirical evidence, and we will try to build a plausible explanation that might have produced the specific outcomes.

\section{Civil-society organizations and socio-economic development}

\subsection{Civil-society organizations}

Since the late 1960s, numerous researchers have been addressing the sphere between the state and the market, sometimes defined as the third sector, non-profit sector, voluntary sector or civil society. Salamon and Anheier (1992) consider that the myriads of definitions rise from the diverging legal backgrounds of the different states, historical factors, the organizations perceived roles and their degree of institutionalization and development. We can distinguish three major definitions of the civil society, mainly based on its perceived function. Habermas $(1996,367)$ describes the civil society with a narrow perception by focusing on its role in public discourse. Secondly, the role of self-constitution is pointed out by Cohen and Arato (1994, x), who define the civil society as the "structures of socialization, association, and organized forms of communication of the lifeworld to the extent that these are institutionalized or are in the process of being institutionalized." Lastly, focusing on representation, the European Commission in its White Paper on Governance considers that the "civil society includes all those voluntary and non-profit organizations which play an important role in giving voice to the concerns of citizens and in delivering services that meet people's needs." In general, the civil society mediates between the private sphere and the government, supports service delivery and serves as a platform for social life. It is composed of more or less formalized institutions that have a voluntary character.

The Hungarian civil society is heterogeneous, and its functioning was influenced by three major laws. First, in 1987, before the fall of the socialist regime, 
Act 74/A.\$ of the Civil Code was introduced. This authorized the establishment of foundations that serve the general public and address public-benefit issues. Next, Act XCII of $1993^{3}$ on civil-society organizations served as the legal background necessary for establishing three new types of civil-society organizations (CSOs): public benefit companies (közhasznú társaság), public foundations (közalapitvány) and public bodies (köztestület). According to Act IV of 2006 ${ }^{4}$, no additional public foundations or public benefit companies can be established anymore, and the existing public benefit companies have to turn into "non-profit companies" (non-profit gazdasági társaság). Lastly, Act CLXXV of 2011 differentiates between the various forms of CSOs and defines them as composed of associations (egyesületek and társaságok) and foundations (alapitványok). Based on this legal definition, the following entities are not part of the civil society: political parties, foundations related to political parties, public foundations, unions and mutual-insurance associations.

The Hungarian Central Statistical Office divides the CSOs into three major groups. The first group is made up comprising private foundations, associations and unions. Secondly, it refers to the non-profit enterprises, which include non-profit companies and public foundations. The last group is defined as interest representation and contains public bodies, employers' organizations, trade unions and professional organizations, seeking to further a particular profession. According to the data provided by the Statisztikai Tükör (Hungarian Central Statistical Office) ${ }^{5}, 87$ percent of the country's third sector in 2014 comprised classical civil organizations of a "public benefit character."

Given the specific Hungarian legal forms of the different organizations of the civil society, we use a rather functional definition; when we refer to civil-society organizations, we focus on grass-roots organizations, interest groups, civic associations and foundations that were self-constituted and that have a meaningful voluntary component. Based on this definition, a foundation established by a local government does not qualify as "self-constituting", therefore we regard it as a local governmental agency.

\subsection{The puzzle}

Our research tackles an important ambiguity present in the authoritative literature on the causal relationships between the civil society, general socio-economic development and government policies aiming at improving these. We outline three main propositions found in the literature.

Will lively associational life lead to socio-economic development?

3 http://mkogy.jogtar.hu/?page = show\&docid $=99300092$.TV.

4 http://njt.hu/cgi_bin/njt_doc.cgi?docid=101618.254511.

5 https://www.ksh.hu/docs/hun/xftp/stattukor/nonprofit/nonprofit14.pdf. 
Putnam $(1993,664)$ states that "features of social life - networks, norms and trust ... enable participants to act together more effectively to pursue shared objectives." He considers that these networks require a strong civil society manifesting itself in abundant memberships in clubs, co-operatives and voluntary associations. The norms learned in these social interactions and the networks formed during these activities are the primary source of socio-economic development. The importance of norms, both formal and informal, is underlined by Bourdieu (1986), as well. According to him, informal networks play the leading role in the economic exchange, thus defining its growth. Ostrom (1990) points out that the norms of cooperation arise through repeated community actions and that these norms should be considered when elaborating policies. The plausible causal mechanisms described in these models could be presented as follows:

\section{Figure 1}

Model 1

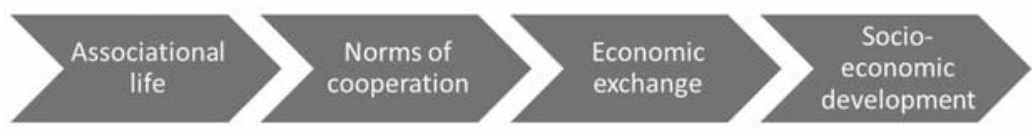

In this case, the government does not need to take measures to encourage associational life because the associations that already exist are the ones that form the norms of cooperation. Thus, the government's role is restricted to enforcing the rules of cooperation.

Is capacity building of CSOs a precondition of socio-economic development?

Development agencies reason that individuals would pick up the norms and skills necessary for dealing with collective decision-making problems, which in turn will lead to democratic stability and economic growth. This belief encourages agencies to invest in civil-society organizations (Hearn 1999; Williams and Young 1994). In addition, in CEE countries several policies were implemented in order to facilitate CSOs' capacity building, ranging from tax breaks for individual or corporate donor to normative subsidies of local or central governments. Therefore, the theoretical model presents another plausible causal mechanism that looks like this:

\section{Figure 2}

Model 2

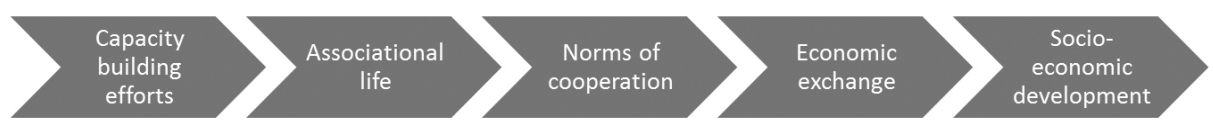


On the other hand, investing in capacity building or strengthening civil-society organizations will not automatically and unquestionably lead to the anticipated socio-economic benefits. Firstly, not all types of associational activities promote norms and foster cooperations that lead to economic development and strong democracy (Fukuyama 1995; Durlauf 1999; della Porta 2000; Hooghe 2003). A society rich in voluntary organizations and active civic engagement in itself does not necessarily lead to positive effects. As Berman $(1997,402)$ argues, the abundant civic life of interwar Germany in the 1930s led to the rise of fascism. Second, studies have found that civic engagement and clubs might strengthen the bonding among the members without having a positive spillover effect over the larger society (Granovetter 1985; Knack 2002). Thirdly, Carothers et al. (1999) show that an abundant civil society, such as in Bangladesh, does not lead to economic development and that strengthening the economy is quite possible without the presence of a large voluntary sector. Finally, investing in the capacity building of the former communist countries' civilsociety organizations poses yet an additional challenge. The past authoritarian regimes have either controlled or banned associational life (Skovajsa 2008; Ványolós and Hajnal 2013), and the civil society of this region remained surprisingly weak even after several years of the state socialism's fall (Petrova and Tarrow 2007). Foreign donors invested a vast amount in the strengthening of the civil society (Pinter 2001), yet membership in associations has not increased, and in certain cases it has even dropped, as empirical studies suggest (Howard 2003; Celichowski 2004; Bocz 2009; Wallace et al. 2012; Voicu 2013).

Are socio-economic development and capacity-building efforts necessary and - jointly - sufficient conditions of a vibrant associational life?

Some scholars, looking especially at the post-communist areas, have theorized that the weakness of the Central and Eastern European (CEE) countries' civil society cannot be explained only through the former regime's effects. Howard (2003) focuses on post-communist Europe's civil society, stating that a "prerequisite for the development of civil society involves economics" $(2003,17)$. Similarly, Petrova (2007) concludes that in the case of the CEE countries, socio-economic development is a necessary precondition of a strengthened associational life. Therefore, the last model of a plausible explanation for the causal mechanism between our key variables is as follows:

Figure 3

Model 3

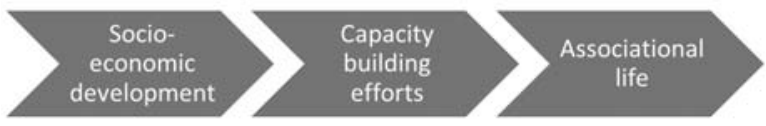


Even though capacity-building efforts are not a consequence of socio-economic development per se, in order to offer a true chance for creating associational life a certain socio-economic development level has to be attained prior to launching any (meaningful) capacity-building effort. Yet, by looking at Eastern Germany's case, Padgett (1999) shows the same weaknesses of the civil society as one finds in other post-communist countries of Eastern Europe: Even though it had adopted the West German model, ensuring a relatively stable economic background, the membership in trade unions and business associations was, in the post-unification period, rapidly declining.

In summary, current scholarship does not offer a conclusive view regarding the causal relationship between capacity-building efforts, lively associational activity and socio-economic development. It does appear that associational activities do contribute to creating and nurturing collective norms that foster cooperation. On the other hand, not all types of associations will lead to a cohesive society or to economic development. The decreasing membership rates in associations of postcommunist Europe limits the success of any type of government intervention aiming to strengthen the civil society.

The ambition of our case study, which reports here on one Hungarian village, is to contribute to this debate and to be a step towards eliminating the fundamental ambiguity outlined above. It cannot, of course, by itself affirm any particular theoretical pattern. But we believe that our observations enrich the evidence available for understanding the emergence of a civil society and the results from strengthening it. We expect that by comparing the plausibility and the explanatory power of different theoretical propositions in the Central and Eastern European context it can orient future research into this, so far largely neglected, problem area.

\section{The approach taken}

\subsection{Research question, data and method}

Our ambition is to decrease the above-described theoretical uncertainty by examining a case of a Hungarian local community and local government: the village of Rozsály.

Rozsály is not a "representative case" in any sense. Rather, we chose it on the basis of theoretical considerations, as a sort of "exemplary case" (Yin 2011). It is exemplary in the sense that the continuity, historical length and breadth, as well as the intensity of its associational life seemed, on the basis of our preliminary investigation, outstanding. Moreover, there seem to be arguments supporting the view that this high level of civil-societal activity has indeed led to particular beneficial outcomes in the local economy. Therefore, we will examine how the local process unfolded within the triangle of local governmental capacity-building policies, civil- 
society dynamics and tangible socio-economic outcomes. This is expected to be informative in different ways.

If evidence suggests that there is no causal connection between capacity-building efforts on the one hand and increased associational life and sustained economic growth on the other, then the case becomes a "critical case" (Yin 2011) with regard to Model 2. That is, given the exceptionally devoted and prolonged (local) governmental efforts aiming at strengthening the capacity of the local civil society, the conclusion would be that "if it does not work even here then it is unlikely to work anywhere else"; at least not in sufficiently similar contexts characterized by similar socio-economic features and paths of past development. If, however, the workability of the intervention seems plausible, then the case study could evolve into a sort of explanation-building endeavor aimed at describing particular mechanisms leading from local-government interventions to their hypothesized outcomes.

Our research question thus seeks to contribute to the ongoing debate regarding the possibilities of developing and strengthening the civil society in CEE countries. In this environment where the associational activity is very low, the possibilities of changing the pattern seem unrealistic and the chances that an abundant civic activity would be created are unlikely. The research question fits in this debate and reads as follows:

\section{RQ: To what extent do Models (1) to (3) depict causal links between govern- mental capacity building, associational life and general socio-economic devel- opments in the view of the Rozsály experience?}

So far no academic research has documented the existence of lively associational life and a strong civil society in Hungary. Our research aims to describe this exemplary case, where at the local level there is an abundance of civil-society organizations and a very active associational life.

It appears that Rozsály is an exemplary case as a result of three key components: the local government's measures, an abundant associational life and a socioeconomic development that took place over the past 23 years. In order to facilitate an accurate replication of our research process, we define our variables as follows:

- Our independent variable is the local government's efforts to strengthen and to encourage associational life. The key local actors are the mayor and the council members.

- There are two dependent variables: firstly, the strengthened associational life represented by the number of both formal and informal voluntary groups and the number of individuals being active in any of them. The second dependent variable is the socio-economic development.

In collecting the data, we have used the village's website, its numerous videos, and publicly available documents, national and international media reports. The 
research relies on such additional primary sources as semi-structured interviews conducted with the local actors. Six such interviews were carried out in the course of spring 2016, each lasting on average an hour. Interviews were carried out with the mayor; the leader of a foundation; a council member who was also a member of an association; and three leaders of three major associations (Teleház, Hajnalpelika Kulturális Egyesület and a local choir). The interviews were tape-recorded, then transcribed. The documents of written records were analyzed using MaxQDA qualitative-analysis software. Codes concerning specific elements of the research questions were created and assigned to specific texts.

The research question involves causal attributions between complex phenomena and corresponding concepts at a high level of abstraction. We will use the process-tracing method to uncover a plausible causal path that possibly produced our outcome of interest (Beach and Pedersen 2013). In the first stage of analysis, we set a modest ambition and attempted to:

- establish that the observable changes in our key variables - namely (i) local governmental capacity-building efforts, (ii) strengthened associational life and (iii) sustained socio-economic development processes - did in fact take place;

- examine whether these changes can be explained through either one of the theoretical models deducted from existing explanations;

- unveil and contrast the views of key local actors regarding the causal connections scrutinized here (including, in particular, agreements, disagreements and blind spots between those views);

- look for compelling pieces of evidence regarding changes in our key variables and their interconnections ("smoking guns", "confessions" and "comprehensive story lines"; Blatter and Haverland 2012, 110-118); and, in the final analysis move towards specifying the micro-mechanisms enabling and triggering, or possibly hindering and prohibiting, change in the given empirical context, and possibly building an explanation of a plausible causal mechanism.

In order to explain the outcomes found in Rozsály, we will use the outcome-explaining process-tracing method (Beach and Pedersen 2013). We will try to establish a minimally sufficient explanation for why the outcome has been produced in this specific case. To this end, we will follow the time sequence of major events that can be attributed as trigger points for further events. In this specific case, we will focus on our three major variable's key events, namely the local governmental capacity building, the socio-economic development and the associational life.

We operationalize our key variables as follows:

- Governmental capacity building involves local governmental policies and activities pursued in order to strengthen associational activities. 
- By socio-economic development we mean tangible improvements in the wellbeing of the (most vulnerable strata of) local population either in terms of social/public services accessible to them or increased capacity to engage in fruitful economic exchange.

- Strengthened associational life: we will use Putnam's approach, namely abundant memberships in clubs, co-operatives and voluntary associations.

\subsection{The rationale of the case selection}

Rozsály is a Hungarian village of 800 inhabitants, situated at the North-Eastern part of the country in Szabolcs-Szatmár-Bereg County, bordering Slovakia, Ukraine and Romania. Over the past ten years, the county has had the highest unemployment rate in Hungary, above 21 percent in both 2009 and 2011. The national average unemployment rate for the same period was, respectively, 9.8 percent and 11.8 percent. While the official unemployment rate of the county decreased to 12.6 percent in $2015^{6}$, it is still among the highest percentages in Hungary, and the average netwage increase is below the national rate. ${ }^{7}$ In 2013 , about 49 percent of the registered unemployed in Hungary had a maximum of 8 years of completed education (out of the currently 10 years total in Hungary's school system); 26 percent of the unemployed had finished vocational school; 22 percent had a high-school diploma; and only 3 percent were college graduates.

Unemployment in Rozsály is in line with the general trends of the region: In 2014, out of 800 total inhabitants, 75 were registered unemployed (9.4\%), which was lower than the county's average.

\section{Empirical findings}

In the following we describe the developments that have taken place in Rozsály with regards to our three key variables.

\subsection{Socio-economic development}

Most of the socio-economic development observed and documented in academic literature (Szabó et al. 2014) and the national and international media (such as Tamás Velkei in Magyar Nemzet article on January 29, 2009, or Jim Reed in BBC article on December 28, 2011) is attributed to the local council, acting either directly or through its agency, the Foundation. After the democratic changes of the 1990s, Hungarian local councils hastily erased the remains of the prior forced collectivization by giving back the lands and other goods of the collective farming

6 Note that the change can, presumably to a significant extent, be attributed to changes in the method of calculation.

7 http://www.ksh.hu/docs/hun/xftp/megy/134/szab134.pdf. 
(Termelöszövetkezet) to their original owners. In contrast to this trend, the local council of Rozsály decided to keep for itself as much field land as possible (originally 85 ha, now 90 ha or 210-220 acres) and to use it for the village's benefit. Since local councils cannot own land and other goods, the local council established the Local Public Benefit Foundation for the Village of Rozsály (Rozsály Községért Jóléti Szolgálat Helyi Alapitvány) in 1993, referred to simply as the Foundation henceforth. The Foundation became the owner of the land and started working it to benefit the community. The Foundation's activities made it stand out from other small Hungarian villages that were struggling with deep poverty, unemployment and an inability of the local authorities to provide for the basic needs of their inhabitants (Szabó et al. 2014, Orbán 2015).

The agricultural, farming and economic activities run by the Foundation aim to support individuals with the greatest financial need, and the Foundation's intention is to keep both goods and businesses local. Most of the farmland is worked by economically disadvantaged locals and/or those who are part of the public employment program. The crops produced are fed to the animals of the Council, which are slaughtered at the local slaughterhouse owned by the local authorities and operated by the Foundation. The meat, along with the locally grown fruits and vegetables, is incorporated into government-provided meals for children in schools and for qualifying individuals as part of the social-service system. Through the Foundation's operations, meat that is not used in preparing the meals gets packed, frozen and sold in the local store at a discounted price.

Today, the local council and the Foundation operate a series of agricultural machines and equipment to work their own fields, as well as the fields of villagers at a discounted price. Thus, numerous elderly and primary producers are able to work their lands and grow their own fruits and vegetables, as well as have some of their fire wood cut. The local shop owned and operated by the Foundation since 2011 provides primary producers a place to sell their goods, and it does not charge any fees nor make any profit from this service. Through the agricultural economic activities offered by the Foundation, individuals struggling with financial hardship have a stable income, and through a public-employment scheme, their basic nourishment is ensured. In addition, some individuals who do not have bathrooms and running water in their homes, in 2007 gained access to some basic social services, such as the public washrooms and shower rooms offered by the Foundation. This way children and adults can have a clean and groomed look, which increases their chances of social integration.

In 2003, the municipality's learning and informational center was established as part of the Foundation's activities. The center offers access to the internet and basic IT and foreign language (English and German) courses. By closing the digital gap, several individuals were able to find employment. 
By finding a solution to the vicious circle of unemployment and poverty, Rozsály has come to be known as the self-sustaining village, or the village that has helped itself out of deep poverty.

\subsection{Associational life - Local civil-society organizations and their development}

The very first civil-society organization of the village was a drama club established sometime in the 1950s, during the socialist era. Next, the sports association was founded in 1979. Among the CSOs established after the political changes, the first institution was the Foundation, using a top-down method employed by the local council. Given the specific Hungarian legal background, it is considered part of the CSOs, a public-benefit organization, but because of its structure, in our analysis we regard it as a local government agency, and we treat it separately from civil-society organizations.

When asked how the majority of the associations came to exist and whether they were top-down or bottom-up initiatives, interviewees' opinions and perspectives diverged. Some believe that there are associations that were created as a somewhat instant solution to one of the community's problems, hence being completely self-organizing and bottom-up.

People were interested in something, so they just gathered and have started doing it. (NGO leader 2)

One interviewee disagreed and believed that it is extremely hard to mobilize individuals:

It's not that people are so motivated by themselves ... I really think that things have changed when Zoli (the mayor) arrived. ... They need a leader who mobilizes them; otherwise, there is no way it would work. (NGO leader 1)

Even if opinions diverge on the direction of creation, these initiatives were always encouraged and strengthened by the mayor in both his formal and informal leadership roles, as will be shown in the section below.

In the following table we aim to give a summary of the main CSOs of the village with the year of their establishment. In the case of the informal groups, the years stated are only an approximation since in many cases meetings were suspended for shorter or longer periods of time before becoming regular activities. 


\section{Table 1}

Local civil-society organizations

\begin{tabular}{|c|c|c|c|}
\hline \multicolumn{2}{|r|}{ Formal organizations } & \multirow{2}{*}{ Field of activity } & \multirow{2}{*}{ Established } \\
\hline & Name & & \\
\hline 1 & Drama Club - no formal name & Cultural & $1950 \mathrm{~s}$ \\
\hline 1 & $\begin{array}{l}\text { Rozsály Sports Association (Rozsály } \\
\text { Sportegyesület) }\end{array}$ & $\begin{array}{l}\text { Two volleyball groups and a } \\
\text { table tennis club }\end{array}$ & 1979 \\
\hline \multirow{4}{*}{2} & \multirow{4}{*}{$\begin{array}{l}\text { Local Public Benefit Foundation } \\
\text { for the Village of Rozsály (Rozsály } \\
\text { Községért Jóléti Szolgálat Helyi } \\
\text { Alapítvány) }\end{array}$} & Social services & \multirow{4}{*}{1993} \\
\hline & & $\begin{array}{l}\text { a. Since 2003: The learning } \\
\text { and informational center } \\
\text { (Teleház) }\end{array}$ & \\
\hline & & b. Since 2007: Rozsály TV & \\
\hline & & $\begin{array}{l}\text { c. Since 2009: Béres András } \\
\text { Kör with its three groups }\end{array}$ & \\
\hline 3 & $\begin{array}{l}\text { Foundation for the Children and } \\
\text { Future (Gyermekekért és a Jövőért } \\
\text { Alapítvány) }\end{array}$ & Social services, education & 2001 \\
\hline 4 & $\begin{array}{l}\text { Local Market Public Benefit } \\
\text { Association (Helyipiac.hu Közhasznú } \\
\text { Egyesület) }\end{array}$ & Local development & 2011 \\
\hline 5 & $\begin{array}{l}\text { Hajnalpelika Small Stage Cultural } \\
\text { Association (Hajnalpelika Kisszínpad } \\
\text { Kulturális Egyesület) }\end{array}$ & $\begin{array}{l}\text { Cultural } \\
\text { Two groups: separately for } \\
\text { children and adults }\end{array}$ & 2012 \\
\hline \multicolumn{4}{|c|}{ Informal groups } \\
\hline 6 & $\begin{array}{l}\text { Church choir (Református } \\
\text { asszonykórus) }\end{array}$ & Cultural & 2013 \\
\hline 7 & Elderly club & Social and leisure & 2007 \\
\hline 8 & $\begin{array}{l}\text { Gipsy Folk Ensamble (Cigány Népi } \\
\text { Együttes) }\end{array}$ & Cultural & $2012-2014$ \\
\hline 9 & Zither and piano club & Cultural & 2012 \\
\hline 10 & HRB Rock band & Cultural & 2014 \\
\hline 11 & Fishing Club & $\begin{array}{l}\text { Sports } \\
\text { Two groups: children and } \\
\text { adults }\end{array}$ & 2014 \\
\hline
\end{tabular}

Source: Compiled based on interviews, the local council's website and media sources.

Based on the presented table, we can see that seven out of eleven groups were established after 2011. In Rozsály, all generations are included in various civic activities. Children act in plays, sing or recite poems, while teens mainly participate in sports clubs. The majority of adults sing in the choir, act or dance and participate in various national and international guest appearances. The elderly have their own meetings and events.

While it is impressive that the number of civic groups has increased, it is important to assess the number of individuals belonging to them when evaluating the 
associational life. Given that half of the groups are informal and have a relatively high fluctuation of membership, we use as a measurement tool the number of participants who were present at a closed-circle celebration dedicated to individuals who took an active role in the community's life. For the event, only individuals active in one of these social groups and their close family members were invited. (In the case of children, their parents and siblings were invited, while in the case of adults, their spouse and children were invited.) In the first year, in 2012, only 33 percent of villagers participated, but in 2015, just three years later, 80 percent of inhabitants attended the celebration. Based on this data, we can state that the lively associational life has amply grown in the four years since 2012, which was just six years after the new mayor was elected.

\subsection{Local government's measures to strengthen the civil society}

From the 1990s on, the initial funding of the Foundation came from central governmental and EU pre-accession grant opportunities (PHARE funds). Later, the Foundation became part of a larger national network, the Association for Life Long Learning (Szövetség az Életen át Tartó Tanulásért), and started to receive additional national and EU funds. After reaching some extent of financial stability the Foundation started to offer financial support for other small local organizations. Additionally, through the Foundation, several associational endeavors have gained a legal background and easier access to financial resources and grants, thus being able to start their own activities. The local government has encouraged and supported the creation of grassroots organizations and often uses its Foundation to give necessary legal or financial background to various initiatives. For example, one of the cultural associations (Béres András Kör) has been legally a part of the Foundation since 2009 - this way it is easier to apply for grants and to support its own activities.

The current mayor has played an active role in encouraging civic life both in his formal role and as a charismatic leader active in several organizations. We regard recording and broadcasting the various events and celebrations that were organized by the local civic groups as one of the first measures to strengthen the civil society. To strengthen the bonds between locals, the Foundation bought a local TV channel and has maintained it since 2007. In addition to raising the social image of individuals who "participate in the life of the village," the TV channel also facilitates trade among members of the community and 14 additional small villages through its teletext.

Another important measure was the earlier mentioned closed circle celebration of 2012. The exclusive nature of the event motivated individuals to assume roles in various voluntary organizations. Moreover, the mayor tried to make the villagers learn to appreciate the community's value by sometimes not approving certain proposed community events. 
Other measures taken by him aimed to minimize rivalry and to build upon existing strengths of their neighboring municipalities.

No, this time I said no to the football team. In Tiszabérke there is a football team, one quarter of the players are from Rozsály... For what? Let them have the football team, we will focus on other sports. [Mayor]

\subsection{Contrasting the three models}

The following section will attempt to compare the theoretical models of causal mechanisms and examine whether they could fit the empirical evidence gathered in Rozsály.

Accordingly, Model 1 presumes lively civic activity as a "prime mover". At first sight, the case of Rozsály does seem to fit this model since it has a history of civic activism. From the logic of the model, we could expect that having a history of civic activism has allowed the village to develop norms favorable to economic exchange. Indeed, having employment or going to school regularly and belonging to groups and associations is considered by most locals to be a way to develop self-esteem and to prevent social challenges associated with long-term unemployment.

... we don't have the so called "roma-problems". Here, most of them work, and there are no generations growing up which would see that their parents did not work and the money would have been brought by the postman. [Foundation's leader]

The next phase of Model 1 suggests that these norms should have led to socioeconomic development. Conversely, however, the empirical evidence suggests that the socio-economic development - the major building blocks of which were outlined earlier - was, rather, a result of the local government's purposive actions rather than the result of dominant social norms. In other words; this model does not seem to be operational in the context of the case examined here. Moreover, the temporal sequence of changes in these two variables seems to refute the proposition inherent in Model 1: on the one hand, most of the developments in associational life (the hypothesized cause) occurred after 2012 while, on the other, major socio-economic development outcomes (the hypothesized effect) were achieved earlier, from 1993 to 2007. Therefore our evidence gives little support to Model 1 .

As to Model 2 even before the democratic transition of 1989-1990, the village had shown some associational activity. In this particular case, the initial heavy investment of the 1990s into the Foundation (through PHARE and similar measures) has proved to be extremely beneficial in the long run, since several other civil-society organizations were able to start their own activities. Importantly, however, this happened only several years later, mostly after 2010. The more important and short-term outcomes of the Foundation's activities were - as we demonstrated 
earlier - the visible improvement in the socio-economic conditions of the village. In other words, the temporal sequence of major changes in (i) associational life and (ii) socio-economic development rule out (or, at least, do not support) the cause-andeffect relationship between these two variables put forward by Model 2 .

Lastly, we turn to Model 3. According to the data gathered, the sequence of events shows that addressing basic socio-economic needs (which, by and large, happened in the 1990s) preceded local governmental interventions aimed at improving associational life as these efforts took place mainly from the second half of the 2000s on only. Therefore we may conclude that our empirical data are congruent with the assumptions of Model 3.

The plausible alternative models presented offer a useful frame and point towards several elements that were necessary to reach the unusual outcome: the history of civic activity, the importance of norms of cooperation, social and economic development and the investments in the civil society. While Model 1 and Model 2 do not provide a plausible explanation for the unusually active civil life present in the village, Model 3 cannot be falsified or refuted on the basis of our empirical findings.

\section{Discussion and conclusion}

Although our core theoretical ambition is realized by the above conclusion we consider it an important task to further deepen and detail Model 3 so that it reflects the rich empirical data gathered in Rozsály.

In Model 3 the importance of norms existing before the socio-economic development is minimized or not even mentioned. Here we emphasize two sets of norms.

Firstly we have found that the history of civic activity created values and norms favorable for establishing new civil-society organizations that have active membership. Being part of the drama club in the 1950s or of the sports associations was regarded as desirable by all of the interviewees. Additionally, in their perception, the past is not an abstract conglomerate of individuals or events, but an integral part of current events. For example, the villagers prefer long-term commitments to and from their locally elected officials. Two out of the five current local representatives have been holding their positions for the past 25 years; two have been reelected in their fourth and fifth election rounds, respectively; and the former mayor left his position when he reached retirement. His seat was taken by the son of another older representative, who has held his position for the past ten years. Locals approve of these long-term commitments and unlimited terms because they enable public actors to see major projects through to completion (whereas shorter commitments mean that an opposition party might come in and terminate a project before it 
could even come to fruition). Also, it becomes easier for villagers to hold their representatives accountable.

Where they change it every fourth year, as in the government ... once up, once down, and then each one of them just cares about himself ... eh ... We are doing what we did 4 and 12 years ago ... That's what responsibility is about. [Local council member]

Such an environment - where associational activities have historically been regarded as socially desirable and local representatives are held accountable - is conducive for policies that aim to improve social and economic development within the local community.

Secondly, the norms and working relationships between the local community leaders are very specific and play a crucial role in the Rozsály case. Due to many public actors' multiple simultaneous memberships (e.g. being the mayor, a drama club member and the president of the fishing club all at the same time), it becomes hard to differentiate between their formal and informal roles and between the local council, the Foundation and other associations registered through the Foundation. In some cases, interviewees do not differentiate among these roles, and they simply refer to the institution or group by naming its key figure. Often, they simply refer to the beneficiaries of any one of these associations as "Rozsály," the whole community. Informal leaders of the village also pay attention to showing exemplary cooperation with each other. The importance of partnership was mentioned several times by all interviewees. They all consider that settling differences is much more important that winning a fight. The interviewees all value the friendship and the good relationships that they share, and they all mentioned suppressing their own egos in order to support these valued relationships and their shared goals.

Seeing the strong cooperation between the local council members, the NGO leaders and other individuals with authority tones down the villagers' natural tendencies to engage in rivalry, and it makes them more conscious of their interdependence.

It's not like ... oh, you have established another singing club and now I will not talk to you anymore! And you see ... people watch how you behave and if they see that we are still friends and I go to her club and she comes to my club, they don't hold grudges either. [local NGO leader 1]

Supervisors and leaders are aware of the roles they play in the life of the village, and they conscientiously act as role models for the others. Individuals who take part in the public employment program have a leader who is also a member of the local council; is active at work and in a voluntary association; leads by example; and is competent. By himself, he coordinates seventy employees and ensures that all the work in the Foundation's fields is well done. 
It means that I am here before they all arrive and I open the gates, but I am the one who also closes them ... I can do all the work they are doing ... no one can tell me that that's not possible 'cause I'll just show them how to do it. [Supervisor employed at the Foundation, local council member]

The strong cooperation between the few key actors and their exemplary behavior has demonstrated that collaboration between the state and other actors can, in spite of the earlier perceptions developed during the socialist era, be viewed as beneficial and fruitful. The policies aiming to strengthen the civil society are not perceived by the locals as similar to the compulsory membership in various associations of the former regimes.

Many of them have seen that I can do it, so they have thought: if she can do it, I can do it as well. And they have tried it, and now there are several of them. [Foundation's leader]

The widely accepted rules were reinforced until they became the dominant ones. Being an active member in civic activities and taking part in building the community has become the new norm in Rozsály. It has become desirable to be part of a club or association, and new associations were created in order to include the most interests. In addition, villagers learn to avoid behavior that has a negative impact on the life of the community; after a period of initial gratification, they ultimately get ostracized:

At those huge events with several hundreds of people we did not have fights, and we only had to escort out a single man. And he didn't really do much harm either, he just drank too much, but we thought that it was better for everybody if he left ... [Mayor]

We believe that the Rozsály model - that is, Model 3 supplemented with the dual role of community norms outlined in the above paragraphs - may offer a viable solution to rural communities in their attempts to strengthen associational life. It might, however, be less applicable in urban or metropolitan areas where different norms of collaboration between the state and the civil sector are likely to occur. The high-ranking officials' and other local leaders' personal example, their very strong bonds and excellent working relationships seem less replicable there. Also, other communities' peer-pressure factor may be much weaker. Even if these ideal working relationships existed in some cases, citizens of a large city or metropolitan area likely would not be able to see it and thus would be less likely to copy that behavior.

Still, certain elements of this particular mechanism should be taken into consideration when aiming to strengthen the civil society, as well as refining future theory about it. According to our experience, investment in civil-society organizations will not be effective without policies directed towards community building and local leaders' involvement in the civic life. Policies and social norms that foster 
cooperation instead of rivalry between the state sector and the civil society, and among citizens themselves, should be encouraged.

\section{References}

Almond, Gabriel Abraham and Sidney Verba. 1963. The Civic Culture: Political Attitudes and Democracy in Five Nations. Princeton: Princeton University Press.

Beach, Derek and Rasmus Brun Pedersen. 2013. Process-Tracing Methods: Foundations and Guidelines. Ann Arbor: University of Michigan.

Berman, Sheri. 1997. "Civil Society and the Collapse of the Weimar Republic." World Politics 49(3), 401-429.

Blatter, Joachim and Markus Haverland. 2012. Designing Case Studies: Explanatory Approaches in Small-N Research. Basingstoke: Palgrave Macmillan.

Bocz, Janos. 2009. "Icebergs: Mistaken Beliefs, the Deep Strata of the Hungarian Non-Profit Sector." Civil Szemle 6(4), 24-50.

Bourdieu, Pierre. 1986. "Forms of Capital." In J. Richardson (ed.). Handbook of Theory and Research in the Sociology of Education. New York: Greenwood Press, $241-258$.

Carothers, Thomas, William Barndt and Mustapha Kamel Al-Sayyid. 1999. "Civil Society." Foreign Policy 117, 18-29.

Celichowski, Jerzy. 2004. “Civil Society in Eastern Europe.” In Marlies Glasius, David Lewis and Hakan Seckinelgin (eds). Exploring Civil Society: Political and Cultural Contexts. New York: Routledge, 62-72.

Cohen, Jean L. and Arato Andrew. 1994. Civil Society and Political Theory. Cambridge, Massachusetts: MIT Press.

della Porta, Donatella. 2000. "Social Capital, Beliefs in Government, and Political Corruption." In S. J. Pharr and Robert D. Putnam (eds). Disaffected Democracies: What's Troubling the Trilateral Countries? Princeton, New Jersey: Princeton University Press, 202-228.

Durlauf, Steven. 1999. The Case "against" Social Capital. Madison, Wisconsin: Social Systems Research Institute, University of Wisconsin.

European Commission, European Governance - A White Paper. 25-Jul-2001. p. 1., available at: http://europa.eu/rapid/press-release_DOC-01-10_en.htm, (last accessed April, 29 2016).

Fukuyama, Francis. 1995. Trust: The Social Virtues and the Creation of Prosperity. London: Penguin. 
Granovetter, Mark. 1985. "Economic Action and Social Structure: The Problem of Embeddedness.” American Journal of Sociology 91(3), 481-510.

Habermas, Jürgen. 1996. Between Facts and Norms. Cambridge: Polity 213.

Hearn, Julie. 1999. Foreign Aid, Democratization and Civil Society in Africa: A Study of South Africa, Ghana and Uganda. Discussion Paper 368. Institute of Development Studies, University of Sussex.

Hooghe, Marc. 2003. "Voluntary Associations and Democratic Attitudes: Value Congruence as a Causal Mechanism." In Marc Hooghe and Dietlind Stolle (eds). Generating Social Capital. New York: Palgrave Macmillan US, 89-111.

Howard, Marc Morjé. 2003. The Weakness of Civil Society in Post-Communist Europe. Cambridge: Cambridge University Press.

Knack, Stephen. 2002. "Social Capital and the Quality of Government: Evidence from the States." American Journal of Political Science 46(4), 772-785.

Orbán, Annamária. 2015. "Building smart communities in the Hungarian social economy." Community Development Journal. Dec 28: bsv053, https://academic.oup.com/cdj/article-abstract/doi/10.1093/cdj/bsv053/2607782/Building-smart-communities-in-the-Hungarian-social?redirectedFrom=fulltext (accessed April 12, 2016).

Ostrom, Elinor. 1990. Governing the Commons: The Evolution of Institutions for Collective Action. Cambridge: Cambridge University Press.

Padgett, Stephen. 1999. Organizing Democracy in Eastern Germany: Interest Groups in Post-Communist Society. Cambridge: Cambridge University Press.

Petrova, Tsveta and Sidney Tarrow. 2007. "Transactional and Participatory Activism in the Emerging European Polity: The Puzzle of East-Central Europe." Comparative Political Studies 40(1), 74-94.

Petrova, Velina P. 2007. "Civil Society in Post-Communist Eastern Europe and Eurasia: A Cross-National Analysis of Micro- and Macro-Factors." World Development 35(7), 1277-1305.

Pinter, Frances. 2001. "The Role of Foundations in the Transformation Process in Central and Eastern Europe." In Volker Then and Peter Walkenhorst (eds). Foundations in Europe: Society, Management and Law. London: Directory of Social Change.

Putnam, Robert. 1993. Making Democracy Work. Princeton, New Jersey: Princeton University Press.

Reed, Jim. 2011. "Hungary's Answer to Unemployment: Manual Labour." BBC. December 28, 2011 Available at http://www.bbc.com/news/world-europe-16309078 (last accessed April 15, 2016). 
Salamon, Lester M. and Helmut K. Anheier. 1992. "In Search of the Non-Profit Sector. I: The Question of Definitions." Voluntas: International Journal of Voluntary and Non-profit Organizations 3(2), 125-151.

Skovajsa, Marek. 2008. "Independent and Broader Civil Society in East-Central European democratizations." Taiwan Journal of Democracy 4(2), 47-73.

Statisztikai Tükör: A nonprofit szektor legfontosabb jellemzői. 2014. Központi Statisztikai Hivatal. 2015/98. Available at https://www.ksh.hu/docs/hun/ xftp/stattukor/nonprofit/nonprofit14.pdf (last accessed March 20, 2016).

Szabó, B., J. Bana, L. Posta and F. Buzás. 2014. "Examination of Local Economic Development and Possibilities of Arrangement for Self-Sufficiency." Review on Agriculture and Rural Development 3(2), 447-453.

Ványolós, István and György Hajnal. 2013. "Hungarian Public Administration: From Transition to Consolidation." In Saltanat Liebert, Stephen E. Condrey and Dmitry Goncharov (eds). Public Administration in Post-Communist Countries: Former Soviet Union, Central and Eastern Europe, and Mongolia. Boca Raton: CRC Press, 277-293.

Velkei Tamás: 2009. Rozsály, az önellátó település. Magyar Nemzet. January 29, 2009. Available at https://mno.hu/migr_1834/rozsaly_az_onellato_ telepules-325714 (last accessed March 27, 2016).

Voicu, Malina. 2013. "Membership in Civic Association in Central and Eastern Europe: A Longitudinal Analysis." Journal of Social Research \& Policy 4(1), 5-20.

Wallace, Caire, Florian Pichler and Christian Haerpfer. 2012. "Changing Patterns of Civil Society in Europe and America 1995-2005: Is Eastern Europe Different?" East European Politics \& Societies 26(1), 3-19.

Williams, D. and T. Young. 1994. "Governance, the World Bank and Liberal Theory." Political Studies 42(1), 84-100.

Yin, Robert K. 2011. Applications of Case Study Research. Thousand Oaks, California: Sage. 